\title{
Amyloid $\beta$-peptide Promotes Permeability Transition Pore in Brain Mitochondria
}

\author{
Paula I. Moreira, ${ }^{1}$ Maria S. Santos, ${ }^{1}$ António Moreno, ${ }^{1}$ and Catarina Oliveira ${ }^{2,3}$
}

Received July 25, 2001.

\begin{abstract}
In this work the effect of the neurotoxic amino acid sequence, $\mathrm{A} \beta_{25-35}$, on brain mitochondrial permeability transition pore (PTP) was studied. For the purpose, the mitochondrial transmembrane potential $(\Delta \Psi \mathrm{m})$, mitochondrial respiration and the calcium fluxes were examined. It was observed that $\mathrm{A} \beta_{25-35}$, in the presence of $\mathrm{Ca}^{2+}$, decreased the $\Delta \Psi \mathrm{m}$, the capacity of brain mitochondria to accumulate calcium and led to a complete uncoupling of the respiration. However, the reverse sequence of the peptide $\mathrm{A} \beta_{25-35}\left(\mathrm{~A} \beta_{35-25}\right)$ did not promote the PTP. The alterations promoted by $\mathrm{A} \beta_{35-25}$ and/or $\mathrm{Ca}^{2+}$ could be reversed when $\mathrm{Ca}^{2+}$ was removed by EGTA or when ADP plus oligomycin were present. The pretreatment with CsA or ADP plus oligomycin prevented the $\Delta \Psi \mathrm{m}$ drop and preserved the capacity of mitochondria to accumulate $\mathrm{Ca}^{2+}$. These results suggest that $\mathrm{A} \beta_{25-35}$ can promote the PTP induced by $\mathrm{Ca}^{2+}$.
\end{abstract}

KEY WORDS: Amyloid $\beta$-peptide; permeability transition pore; brain mitochondria; mitochondrial transmembrane potential; calcium fluxes; neurodegeneration.

\begin{abstract}
ABBREVIATIONS: A $\beta$, amyloid beta peptide; AD, Alzheimer's disease; CsA, cyclosporin A; $\Delta \Psi \mathrm{m}$, mitochondrial transmembrane potential; GSH, reduced glutathione; PC12, pheochromocytoma cell line; PTP, permeability transition pore; ROS, reactive oxygen species; $\mathrm{TPP}^{+}$, tetraphenylphosphonium ion.
\end{abstract}

\section{INTRODUCTION}

Amyloid plaque, a pathological marker of Alzheimer's disease (AD), is composed primarily of amyloid beta peptide $(\mathrm{A} \beta)$ (Glenner, 1988). A $\beta$ is an amphipathic, 39to 42-residue peptide, which is derived from the transmembrane amyloid precursor protein by proteolytic cleavage (Selkoe et al., 1995). A smaller, 11-residue fragment of $\mathrm{A} \beta$ ( $\left.\mathrm{A} \beta_{24-35}\right)$ possesses much of the biological activity of the full-length peptide. In vitro investigations provided firm pharmacological data on dose- (Pereira et al., 1998; 1999) and conformation-dependent (Pike and Cotman, 1993) neurotoxic potentials of $\mathrm{A} \beta$. There are several studies suggesting that oxidative stress and altered energy metabolism are involved in the pathogenesis of AD (Smith et al.,

\footnotetext{
${ }^{1}$ Center for Neuroscience and Cellular Biology of Coimbra, Department of Zoology.

${ }^{2}$ Department of Biochemistry, Faculty of Medicine, University of Coimbra, 3004-517 Coimbra, Portugal.

${ }^{3}$ To whom correspondence should be addressed. Center for Neuroscience and Cellular Biology of Coimbra, Department of Biochemistry, Faculty of Medicine, University of Coimbra, 3004-504 Coimbra, Portugal. Tel.: 351-239-820190; Fax: 351-239-822776; E-mail: catarina@cnc.cj.uc.pt
} 
1991; Behl, 1999). Postmortem studies (Kish et al., 1992) demonstrate a decrease in cytochrome oxidase activity in AD brains. However, the critical step of how $\mathrm{A} \beta$ fragments induce cytotoxicity, directly via oxidative mechanisms, is still to be ascertained. According to the model reported by Hensley et al. (1994) distortions of the electronic structure of $\mathrm{A} \beta$ may result in "radicalization" of the peptide and $\mathrm{A} \beta$ itself can act as a free radical. It has been suggested that internalized $\mathrm{A} \beta$, through intimate contacts with intracellular recognition sites, directly damages the membranes of intracellular organelles, such as those involved in the respiratory chain of the mitochondria (Pike and Cotman, 1993). Damage to mitochondrial membranes enhances the production of ROS and compromises neurons by energy depletion. Pereira et al. (1999) showed in PC12 cells that, A $\beta$ induces mitochondrial dysfunction and impairment of glycolysis, leading to ATP depletion, by a mechanism involving the generation of ROS.

Mitochondria have a dual importance in the process of oxidative stress. They are probably the most important source of increased free radical production and thus play a crucial role in generating oxidative stress (Boveris et al., 1972; Loschen et al., 1974). On the other hand, mitochondria are one of the possible targets by which oxidative stress exerts its effects on cellular deterioration (Bindoli, 1988), and this is believed to play an important role in neurodegeneration (Beal, 1996). A potentially central factor in cell death in neurodegeneration is the permeability transition pore (PTP) (Kim et al., 1999; Brustovetsky and Dubinsky, 2000). The PTP is a nonselective, high conductance channel that spans the inner and outer mitochondrial membrane (Bernardi et al., 1994; Zoratti and Szabo, 1995). Experimentally, induction of the PTP is characterized by an abrupt swelling and depolarization of membrane potential accompanied by the efflux of mitochondrial calcium, GSH, and NAD(P)H (Bernardi, 1992; Petronilli et al., 1994), all of which are inhibited by the immunosuppressant cyclosporin A (CsA) (Broekemeier et al., 1989).

The aim of the present study was to investigate the effects of $\mathrm{A} \beta_{25-35}$ on the PTP of brain mitochondria. Mitochondrial transmembrane potential, mitochondrial respiration and calcium fluxes were the parameters examined.

\section{MATERIALS AND METHODS}

\section{Chemicals}

$\mathrm{A} \beta_{25-35}$ and $\mathrm{A} \beta_{35-25}$ were obtained from Bachem AG (Bubendorf, Germany). Protease (Subtilisin, Carlsberg) type VIII was obtained from Sigma. Digitonin was obtained from Calbiochem. All the other chemicals were of the highest grade of purity commercially available.

\section{Isolation of Brain Mitochondria}

Brain mitochondria were isolated from male Wistar rats (six weeks) by a method previously described (Rosenthal et al., 1987), with slight modifications. The rats were killed by decapitation, and the brains were rapidly removed and homogenized at $4^{\circ} \mathrm{C}$ in $10 \mathrm{ml}$ of isolation medium $(225 \mathrm{mM}$ mannitol, $75 \mathrm{mM}$ sucrose, $5 \mathrm{mM}$ 
Hepes, $1 \mathrm{mM}$ EGTA, $1 \mathrm{mg} / \mathrm{ml}$ bovine serum albumin, $\mathrm{pH} 7.4$ ) containing $5 \mathrm{mg}$ of the bacterial protease type VIII (Subtilsin). Brain homogenates were brought to $30 \mathrm{ml}$ and then centrifuged at $2000 \mathrm{~g}$ for three minutes. The pellet was resuspended in $10 \mathrm{ml}$ of the isolation medium containing $0.02 \%$ digitonin (which free mitochondria from the synaptosomal fraction) and centrifuged at $12,000 \mathrm{~g}$ for eight minutes. The mitochondrial pellet was resuspended in $10 \mathrm{ml}$ of medium and recentrifuged at $12,000 \mathrm{~g}$ for ten minutes. Finally, the mitochondrial pellet was resuspended in $300 \mu \mathrm{l}$ of resuspension medium ( $225 \mathrm{mM}$ mannitol, $75 \mathrm{mM}$ sucrose, $5 \mathrm{mM}$ Hepes, $\mathrm{pH}$ 7.4). Mitochondrial protein was determined by the biuret method calibrated with bovine serum albumin (Gornall et al., 1949).

\section{Membrane Potential $(\Delta \Psi \mathrm{m})$ Measurements}

The mitochondrial transmembrane potential was monitored by evaluating transmembrane distribution of $\mathrm{TPP}^{+}$(tetraphenylphosphonium) with a $\mathrm{TPP}^{+}$-selective electrode prepared according to Kamo et al. (1979) using a calomel electrode as reference.

Reactions were carried out in a chamber with magnetic stirring in $1 \mathrm{ml}$ of the standard medium supplemented with $3 \mu \mathrm{M} \mathrm{TPP}{ }^{+}$. The experiments were started by adding $5 \mathrm{mM}$ succinate to mitochondria in suspension at $0.8 \mathrm{mg}$ protein $/ \mathrm{ml}$. After a steady-state distribution of $\mathrm{TPP}^{+}$had been reached (ca. two minutes of recording), $\mathrm{Ca}^{2+}$ was added and $\Delta \Psi \mathrm{m}$ fluctuations recorded. Membrane potential was estimated from the decrease of $\mathrm{TPP}^{+}$concentration in the reaction medium as described elsewhere (Moreno and Madeira, 1991). $\mathrm{A} \beta_{25-35}(50,100 \mu \mathrm{M})$ was incubated five minutes before succinate addition, while $0.85 \mu \mathrm{M}$ CsA and $2 \mu \mathrm{g} / \mathrm{ml}$ oligomycin plus $1 \mathrm{mM}$ ADP were added for two minutes prior $\mathrm{A} \beta_{25-35}$ pre-incubation or mitochondria energization.

\section{Mitochondrial Respiration}

Oxygen consumption of isolated mitochondria was monitored polarographically with a Clark oxygen electrode (Estabrook, 1967) connected to a suitable recorder in a $1 \mathrm{ml}$ thermostated water-jacket closed chamber with magnetic stirring. The reactions were carried out at $30^{\circ} \mathrm{C}$ in $1 \mathrm{ml}$ of the standard medium with $0.8 \mathrm{mg}$ protein. $50 \mu \mathrm{M} \mathrm{A} \beta_{25-35}$ was incubated five minutes before succinate addition. $25 \mathrm{nmol} / \mathrm{mg}$ protein FCCP was added one minute after mitochondria energization.

\section{Mitochondrial Calcium Fluxes}

Mitochondrial calcium fluxes were measured by monitoring the changes in $\mathrm{Ca}^{2+}$ concentration in the reaction medium using a calcium-selective electrode according to previously described procedures (Moreno and Madeira, 1991). The reactions were conducted in an open vessel with magnetic stirring in $1 \mathrm{ml}$ of the reaction medium

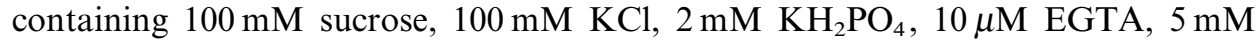
Hepes ( $\mathrm{pH} 7.4)$, with $2 \mu \mathrm{M}$ rotenone. Mitochondria $(0.8 \mathrm{mg} / \mathrm{ml})$ were energized with 
$5 \mathrm{mM}$ succinate after one minute of $\mathrm{Ca}^{2+}$ addition in the absence and in the presence of $\mathrm{A} \beta_{25-35}(50,100 \mu \mathrm{M})$ and $0.85 \mu \mathrm{M}$ CsA or $1 \mathrm{mM}$ ADP plus $2 \mu \mathrm{g} / \mathrm{ml}$ oligomycin.

\section{RESULTS}

\section{Effect of $\mathbf{A} \beta_{25-35}$ on $\Delta \Psi \mathrm{m}$ : Induction of PTP}

The mitochondrial electric potential $(\Delta \Psi \mathrm{m})$ drop is a typical phenomenon that leads to the induction of PTP. In Fig. 1 we can observe the alteration of brain $\Delta \Psi \mathrm{m}$ induced by $\mathrm{A} \beta_{25-35}$. In control conditions (Fig. 1A), after the energization of mitochondria with succinate, the first and second pulse of $125 \mathrm{nmol} \mathrm{Ca}^{2+}$ per $\mathrm{mg}$ of protein led to a rapid depolarization followed by repolarization. However, a third pulse of $\mathrm{Ca}^{2+}$ led to an irreversible depolarization of mitochondria after a smaller repolarization. The collapse of the $\Delta \Psi \mathrm{m}$ is prevented by adding EGTA or oligomycin plus ADP (data not shown) which further led to a complete restoration of the

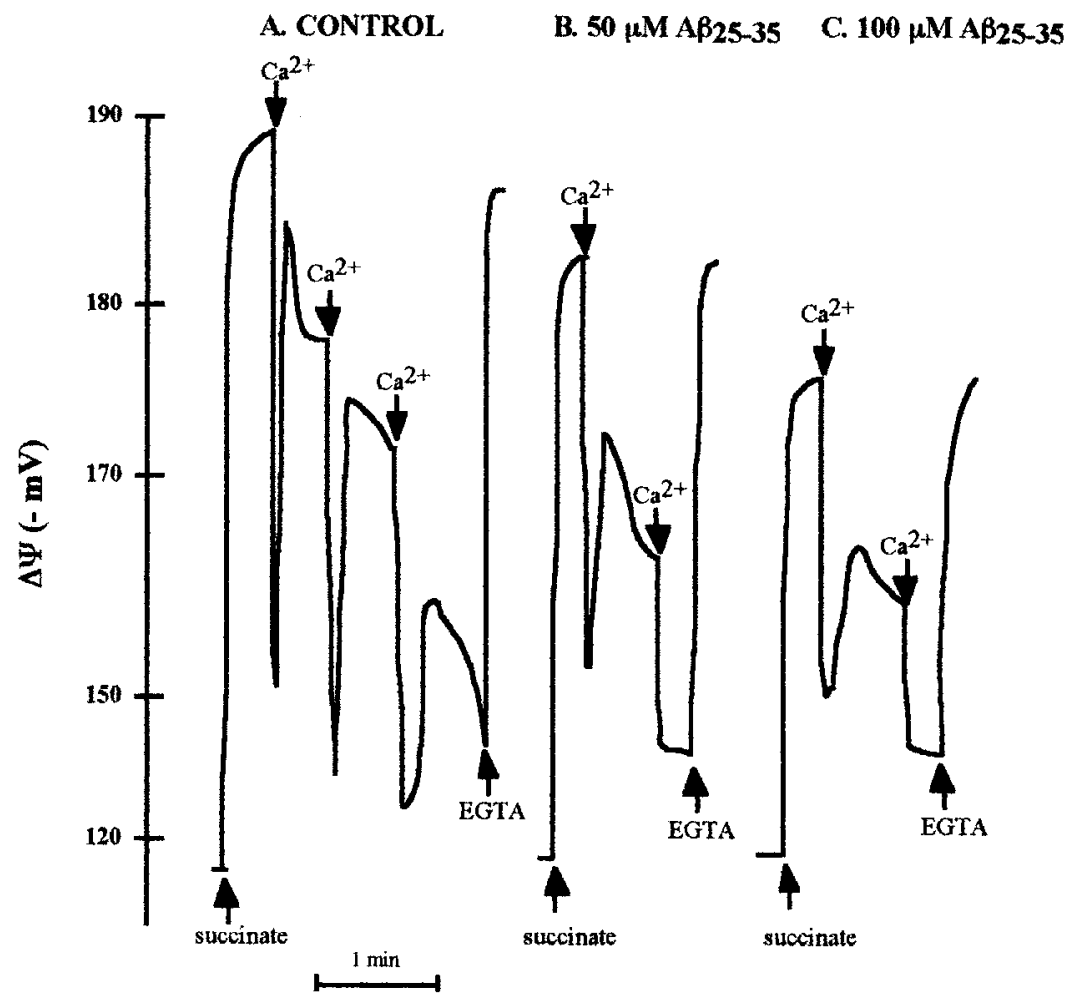

Fig. 1. Effect of $\mathrm{A} \beta_{25-35}$ on mitochondrial membrane potential. Freshly isolated brain mitochondria $(0.8 \mathrm{mg})$ in $1 \mathrm{ml}$ of the standard medium supplemented with $3 \mu \mathrm{M} \mathrm{TPP}{ }^{+}$ and $2 \mu \mathrm{M}$ rotenone were energized with $5 \mathrm{mM}$ succinate. A. $\mathrm{Ca}^{2+}(125 \mathrm{nmol} / \mathrm{mg}$ protein $)$ was added one minute after mitochondria energization. B., C. $50 \mu \mathrm{M} \mathrm{A} \beta_{25-35}$ and $100 \mu \mathrm{M}$ $\mathrm{A} \beta_{25-35}$, respectively, were pre-incubated for five minutes at $30^{\circ} \mathrm{C}$ before mitochondria energization. The traces are typical of four or five experiments. 
$\Delta \Psi \mathrm{m}$ to the state 4 level (e.g., before $\mathrm{Ca}^{2+}$ addition). In the presence of $\mathrm{A} \beta_{25-35}$ $(50 \mu \mathrm{M}$ and $100 \mu \mathrm{M})$ (Fig. 1B, C) a significant decrease of $\Delta \Psi \mathrm{m}$, measured after mitochondria energization, occurred. This decrease in $\Delta \Psi \mathrm{m}$ is more pronounced in mitochondria pre-incubated with $100 \mu \mathrm{M} \mathrm{A} \beta_{25-35}$. These mitochondria were more susceptible to the amount of $\mathrm{Ca}^{2+}$ added; apparently they undergo PTP in the presence of lower $\mathrm{Ca}^{2+}$ concentrations (after two $\mathrm{Ca}^{2+}$ challenges), when compared to the control mitochondria. The drop in $\Delta \Psi \mathrm{m}$ and the increased susceptibility to $\mathrm{Ca}^{2+}$ were dependent on $\mathrm{A} \beta_{25-35}$ concentration.

The reverse sequence of $\mathrm{A} \beta_{25-35}\left(\mathrm{~A} \beta_{35-25}\right)$ did not affect the $\Delta \Psi \mathrm{m}$ as compared with control condition (Fig. 2).

\section{Protection of $1 \Delta \Psi \mathrm{m}$ Afforded by CsA and Oligomycin Plus ADP: Inhibition of PTP}

Pre-incubation (two minutes) of mitochondria with $1 \mathrm{mM}$ ADP plus $2 \mu \mathrm{g} / \mathrm{ml}$ oligomycin afforded complete protection against mitochondrial membrane depolarization, by increasing dramatically the capacity of mitochondria to repolarize the membrane after $\mathrm{Ca}^{2+}$ accumulation (Fig. 3).

Additionally, cyclosporin A (CsA), when added two minutes prior to $\mathrm{Ca}^{2+}$ or $\mathrm{A} \beta_{25-35}$, afforded a clear protection of mitochondria since it prevents the depolarization induced by of $\mathrm{Ca}^{2+}$ when $\mathrm{A} \beta_{25-35}$ is present.

\section{Effect of $\mathbf{A} \beta_{25-35}$ and FCCP on $\Delta \Psi \mathbf{m}$ and Respiration}

To distinguish between a direct or an indirect action of this peptide on PTP, the effect of $25 \mathrm{nmol} / \mathrm{mg}$ protein of FCCP (a mitochondrial respiratory chain uncoupler) (Fig. 4B) was tested. The first pulse of $125 \mathrm{nmol} \mathrm{Ca}^{2+}$ per $\mathrm{mg}$ of protein led to a rapid depolarization followed by an incomplete repolarization. However, a second pulse of $\mathrm{Ca}^{2+}$ led to an irreversible depolarization, a profile similar to that obtained with $50 \mu \mathrm{M} \mathrm{A} \beta_{25-35}$ (Fig. 4A).

Induction of PTP by $\mathrm{A} \beta_{25-35}$ is further evidenced by its effect on mitochondrial respiration (Fig. 4). When the mitochondria were pre-incubated for five minutes with $50 \mu \mathrm{M} \mathrm{A} \beta_{25-35}$, adding $125 \mu \mathrm{M} \mathrm{Ca}^{2+}$ resulted in a complete uncoupling of respiration which was traduced by a continuous stimulation of state 3 respiration. This effect was similar to that exerted by FCCP, in the presence of $125 \mu \mathrm{M} \mathrm{Ca}^{2+}$.

\section{Effect of $\mathbf{A} \beta_{25-35}$ on Calcium Fluxes}

Since the mitochondrial collapse of $\Delta \Psi \mathrm{m}$, associated to $\mathrm{Ca}^{2+}$ overload, is related with PTP opening, experiments were performed to further confirm the $\mathrm{A} \beta_{25-35}$ induction of the PTP opening by studying the $\mathrm{Ca}^{2+}$ retention by energized mitochondria. Figure $5 \mathrm{~A}$ shows that isolated brain mitochondria incubated with $50 \mu \mathrm{M} \mathrm{Ca}{ }^{2+}$ $(125 \mathrm{nmol} / \mathrm{mg}$ protein), in the presence of $2 \mathrm{mM}$ phosphate and energized with succinate, rapidly accumulate $\mathrm{Ca}^{2+}$ from the medium and, after a slow release of some of the accumulated $\mathrm{Ca}^{2+}$, they were able to continue to accumulate $\mathrm{Ca}^{2+}$, thus retaining a large portion of the $\mathrm{Ca}^{2+}$ present in the medium. In the presence of $100 \mu \mathrm{M} \mathrm{Ca}^{2+}$ mitochondria retained only a small amount of $\mathrm{Ca}^{2+}$. When $\mathrm{Ca}^{2+}$ was present in 
A. CONTROL

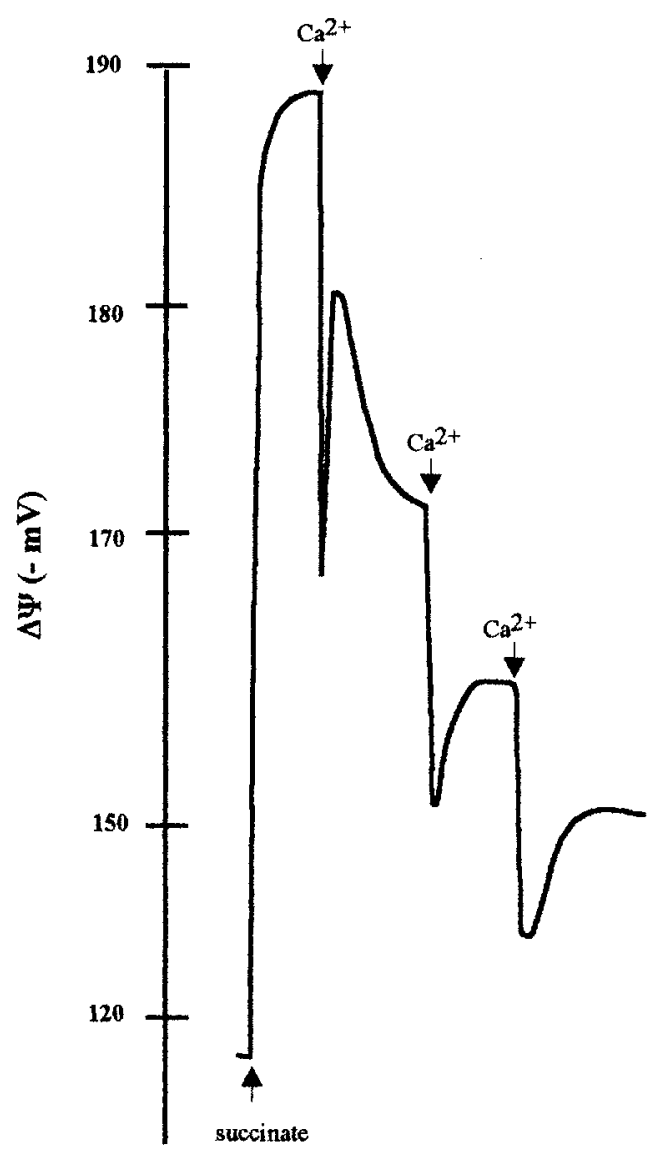

\section{B. $100 \mu \mathrm{M}$ AB35-25}

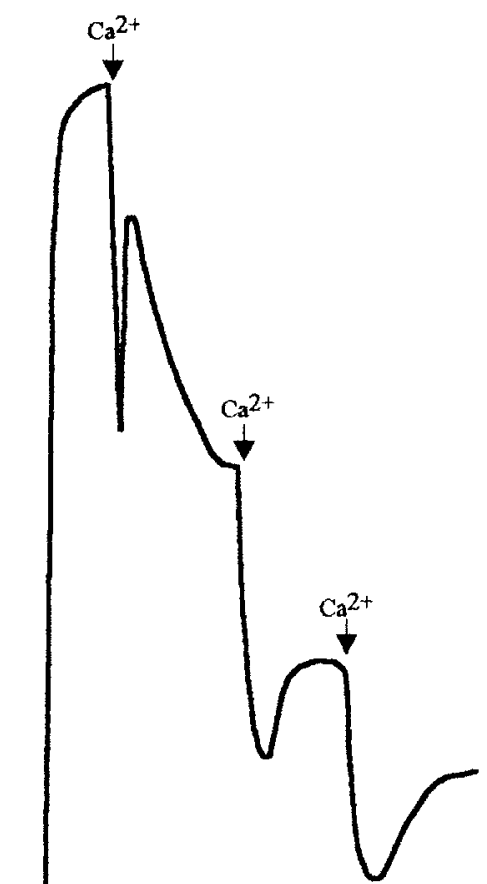

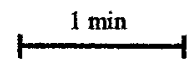

Fig. 2. Effect of $\mathrm{A} \beta_{35-25}$ on mitochondrial membrane potential. Freshly isolated brain mitochondria $(0.8 \mathrm{mg})$ in $1 \mathrm{ml}$ of the standard medium supplemented with $3 \mu \mathrm{M} \mathrm{TPP}{ }^{+}$and $2 \mu \mathrm{M}$ rotenone were energized with $5 \mathrm{mM}$ succinate. A. $\mathrm{Ca}^{2+}(125 \mathrm{nmol} / \mathrm{mg}$ protein) was added one minute after mitochondria energization. B. $100 \mu \mathrm{M} \mathrm{A} \beta_{35-25}$ was pre-incubated for five minutes at $30^{\circ} \mathrm{C}$ before mitochondria energization. The traces are typical of three experiments.

higher doses $(200-300 \mu \mathrm{M})$, mitochondria became unable to retain the accumulated $\mathrm{Ca}^{2+}$ due to PTP opening. In fact, for $100 \mu \mathrm{M} \mathrm{Ca}^{2+}$, the addition of CsA or ADP plus oligomycin, restored the ability of mitochondria to store $\mathrm{Ca}^{2+}$ by avoiding the PTP opening (Fig. 5A).

The presence of $\mathrm{A} \beta_{25-35}$ potentiated the PTP opening (Fig. 5B, C). We also could observe that the effect of $\mathrm{A} \beta_{25-35}$ on calcium fluxes was concentration-dependent, 


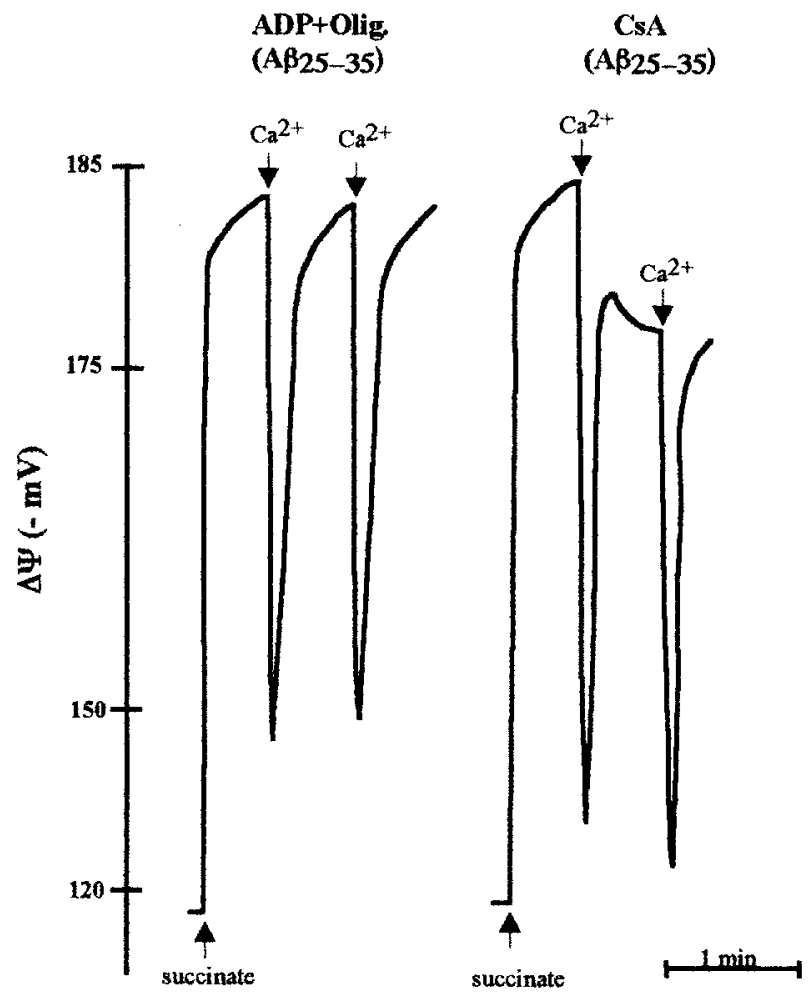

Fig. 3. Inhibitory effect of CsA and oligomycin plus ADP on $\mathrm{A} \beta_{25-35}$-dependent permeability transition pore opening. Mitochondria were incubated at $0.8 \mathrm{mg}$ protein $/ \mathrm{ml}$ under standard conditions as described in Materials and Methods. $0.85 \mu \mathrm{M} \mathrm{CsA}$ and $1 \mathrm{mM}$ ADP plus $2 \mu \mathrm{g} / \mathrm{ml}$ oligomycin were incubated with mitochondria for two minutes before adding $\mathrm{A} \beta_{25-35}$. The two $\mathrm{A} \beta_{25-35}$ (50 and $100 \mu \mathrm{M}$ ) were added five minutes before energizing the mitochondria with $5 \mathrm{mM}$ succinate. The traces are typical of four or five experiments.

i.e., higher $\mathrm{A} \beta_{25-35}(100 \mu \mathrm{M})$ (Fig. 5C) led to a faster PTP opening and, consequently to a smaller calcium retention within mitochondria. These effects on calcium accumulation could be prevented in the presence of $0.85 \mu \mathrm{M}$ CsA and $1 \mathrm{mM}$ ADP plus $2 \mu \mathrm{g} / \mathrm{ml}$ oligomycin. Although both agents contributed for a higher capacity of mitochondria to accumulate $\mathrm{Ca}^{2+}$, the protection exerted by ADP plus oligomycin, as occurred on $\Delta \Psi \mathrm{m}$, was more effective than that exerted by CsA (Fig. 5C, D).

\section{DISCUSSION}

A potentially central factor in cell death in neurodegeneration is the PTP. This channel has been shown to be involved in oxidant-induced mitochondrial large amplitude swelling (Bernardi et al., 1994; Zoratti and Szabo, 1995), $\mathrm{Ca}^{2+}$ release 


\section{A $50 \mu \mathrm{MA \beta 25-35}$}

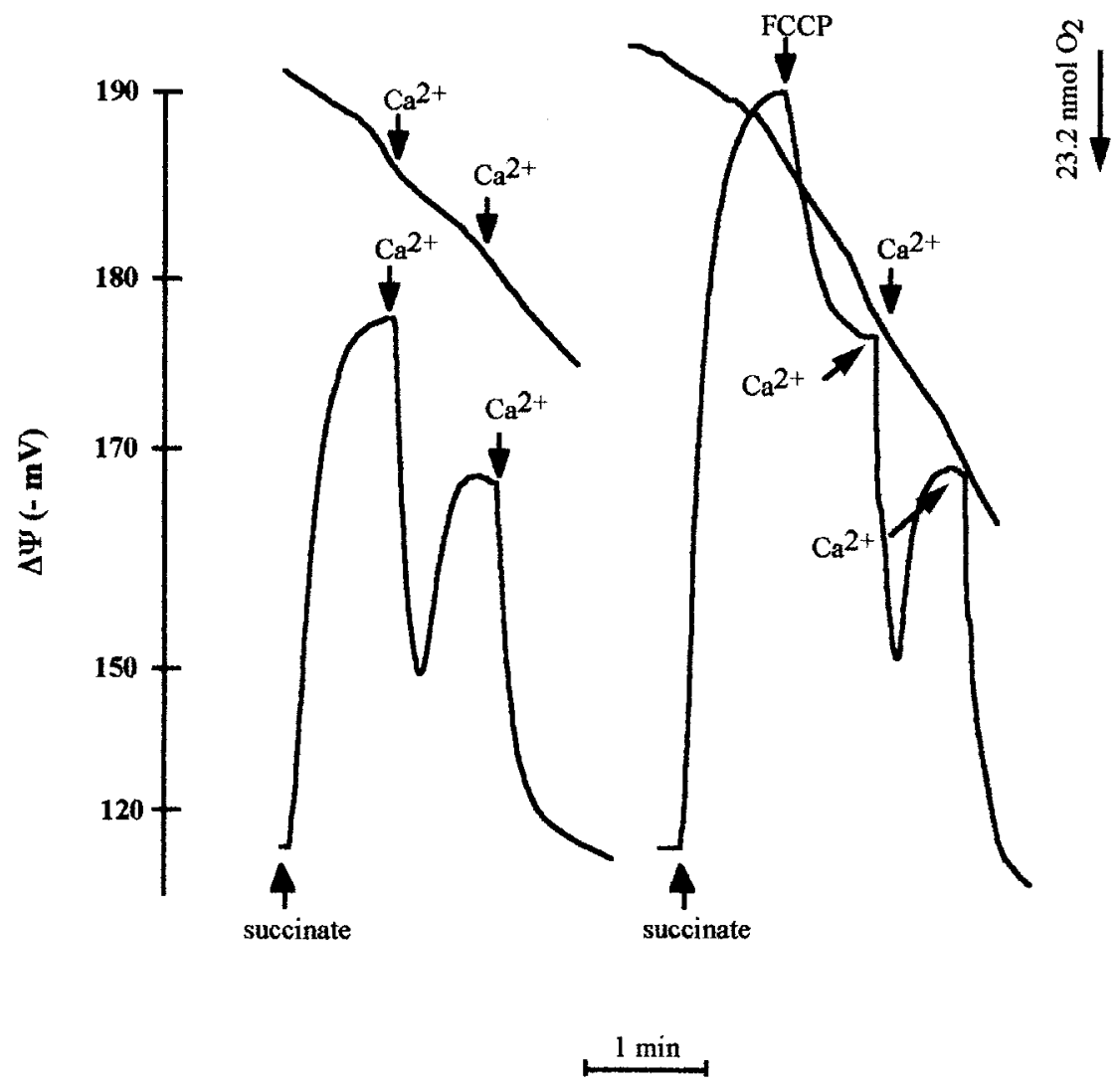

B. $25 \mathrm{nM}$ FCCP

Fig. 4. Effect of $\mathrm{A} \beta_{25-35}$ and FCCP on mitochondrial membrane potential and respiration. Freshly isolated brain mitochondria $(0.8 \mathrm{mg})$ in $1 \mathrm{ml}$ of the standard medium supplemented with $3 \mu \mathrm{M} \mathrm{TPP}^{+}$and $2 \mu \mathrm{M}$ rotenone were energized with $5 \mathrm{mM}$ succinate. A. $50 \mu \mathrm{M} \mathrm{A} \beta_{25-35}$ was pre-incubated for five minutes at $30^{\circ} \mathrm{C}$ before mitochondria energization. B. $25 \mathrm{nM}$ FCCP was added one minute after mitochondria energization. The traces are typical of two experiments.

(Bernardi et al., 1994), and cell death (Marchetti et al., 1996). Pore opening is controlled by membrane voltage and affected by numerous agonists and antagonists. Some of the effectors, which increase the PTP's opening probability, include $\mathrm{Ca}^{2+}$, Pi (Bernardi and Petronilli, 1996) oxidizing agents (Bernardi et al., 1994; Zoratti and Szabo, 1995), atractyloside, and inhibitors of the electron transport chain (Chernyak and Bernardi, 1996).

Several studies have demonstrated the existence of PTP in brain mitochondria (Andreyev and Fiskum, 1999; Kim et al., 1999; Berman et al., 2000; Brustovetsky and Dubinsky, 2000; Kristián et al., 2000). Preliminary evidence from experiments with isolated brain mitochondria (Kristal and Dubinsky, 1997) and neuronal cultures (Dubinsky and Levi, 1998) suggests that neuronal mitochondria can undergo an increase in membrane permeability transition under pathological conditions. 


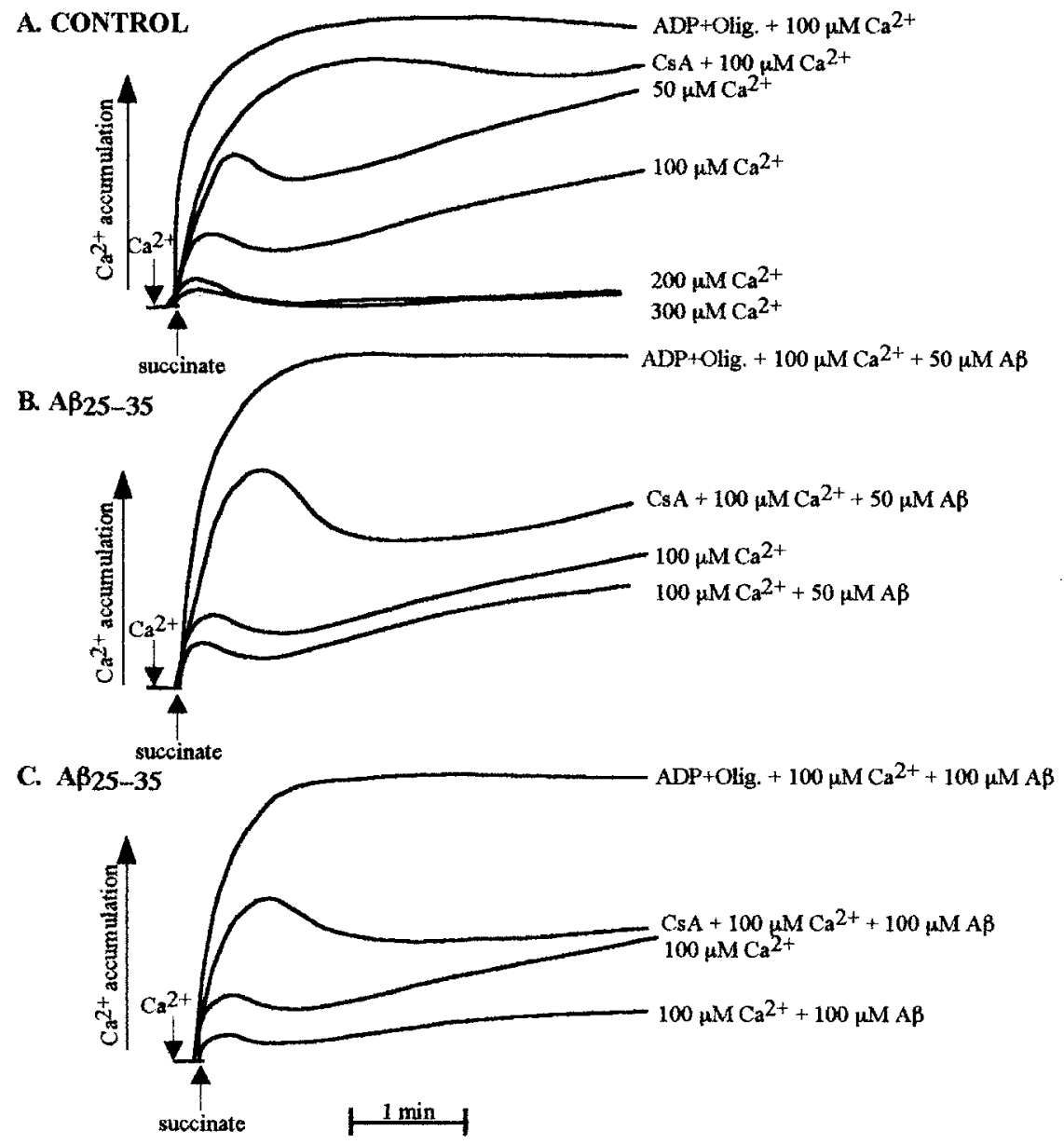

Fig. 5. Effect of $\mathrm{A} \beta_{25-35}$ on calcium fluxes. Mitochondria were incubated at $0.8 \mathrm{mg}$ protein/ $\mathrm{ml}$ under standard conditions as described in Materials and Methods. A. Standard medium was supplemented with different $\mathrm{Ca}^{2+}$ concentrations $(50,100,200,300 \mu \mathrm{M})$ one minute before mitochondria energization with $5 \mathrm{mM}$ succinate. B., C. 50 and $100 \mu \mathrm{M} \mathrm{A} \beta_{25-35}$, respectively, were pre-incubated for five minutes before $100 \mu \mathrm{M} \mathrm{Ca}^{2+}$ addition. $0.85 \mu \mathrm{M} \mathrm{CsA}$ and $2 \mu \mathrm{g} / \mathrm{ml}$ oligomycin plus $1 \mathrm{mM}$ ADP were added to the reaction medium two minutes prior to $\mathrm{Ca}^{2+}$ or $\mathrm{A} \beta_{25-35}$ pre-incubation. The uptake and release of sequestered $\mathrm{Ca}^{2+}$ by mitochondria were monitored as described in Materials and Methods. The traces are typical of three experiments.

In this work, we demonstrate the involvement of $\mathrm{A} \beta$ on the promotion of brain PTP induced by $\mathrm{Ca}^{2+}$. The mitochondrial $\Delta \Psi \mathrm{m}$, mitochondrial respiration and calcium fluxes were the parameters studied since they are hallmarks of PTP. Mitochondrial depolarization favors PTP induction, presumably by lowering thresholds for calcium or oxidants (Bernardi, 1992). Extensive calcium cycling, the continual movement of calcium into mitochondria via the calcium uniporter and out of the mitochondria via the $\mathrm{Na}^{+} / \mathrm{Ca}^{2+}$ exchanger, can also depolarize mitochondria and lead to a membrane permeability transition (Kristal and Dubinsky, 1997). Similarly 
to other studies (Kristal and Dubinsky, 1997; Berman et al., 2000; Kristián et al., 2000) we observe PTP induction by extramitochondrial calcium addition. $\mathrm{Ca}^{2+}$ uptake is concentration-dependent, with higher concentrations leading to a lower amount of $\mathrm{Ca}^{2+}$ being accumulated by mitochondria, indicating a continuous cycling of $\mathrm{Ca}^{2+}$ due to PTP induction. However, there was always a retention of some amount of $\mathrm{Ca}^{2+}$ (Fig. 5) indicating that some mitochondria did not undergo PTP. Kristián et al. (2000) using succinate as substrate observed that, in brain mitochondria, following saturation of the $\mathrm{Ca}^{2+}$ uptake system, a large release of sequestered calcium did not ocur.

$\mathrm{A} \beta_{25-35}$ decreased the $\Delta \Psi \mathrm{m}$ and the capacity of mitochondria to accumulate $\mathrm{Ca}^{2+}$, accelerating PTP induction (Fig. 1B, C; Fig. 5B, C). Parks et al. (2001) demonstrated that, in liver mitochondria, $\mathrm{A} \beta_{25-35}$, in the presence of $\mathrm{Ca}^{2+}$ and phosphate, induces PTP in a concentration-dependent manner. These results are in agreement with other studies demonstrating that $\mathrm{A} \beta$ peptides can cause a harmful elevation of intracellular calcium levels (Mattson et al., 1992). We observe that PTP induction is potentiated in the presence of $\mathrm{A} \beta$ suggesting that $\mathrm{A} \beta$ establishes conditions promoting calcium cycling, and thus, may predispose mitochondria to PTP induction (Fig. 5B, C).

To elucidate between a direct or an indirect action of $\mathrm{A} \beta_{25-35}$ on PTP, we compared the effect exerted by this peptide with that caused by the mitochondrial respiratory chain uncoupler FCCP. For this purpose, we used a small amount of FCCP ( $25 \mathrm{nmol} / \mathrm{mg}$ protein) in order to obtain a decrease in $\Delta \Psi$ similar that promoted by $\mathrm{A} \beta_{25-35}$. Both agents, FCCP and $\mathrm{A} \beta_{25-35}$, produced a similar effect: diminished $\Delta \Psi \mathrm{m}$, the capacity of mitochondria to accumulate $\mathrm{Ca}^{2+}$ (Fig. $\left.1 \mathrm{~B}, \mathrm{C}, 4 \mathrm{~A}, \mathrm{~B}, 5 \mathrm{~B}, \mathrm{C}\right)$ and led to a complete uncoupling of the respiration (Fig. 4A, B). Uncoupling refers to loss of respiratory control, i.e., the proton gradient is no longer coupled to oxidative phosphorylation. Since uncouplers destroy the capacity for ATP synthesis, they are highly toxic compounds. There are numerous evidences (Mattson, 1997; Pereira et al., 1999) indicating an imbalance on energetic metabolism induced by A $\beta$ peptides.

The reverse sequence of $\mathrm{A} \beta_{25-35}\left(\mathrm{~A} \beta_{35-25}\right)$ did not induce the PTP (Fig. 2). This result allows us to conclude that a specific sequence of amino acids is needed for the induction of PTP. Mattson et al. (1993) stated that the "reverse sequence" A $\beta_{35-25}$ is not cytotoxic. Also, in a cell-based assay, $\mathrm{A} \beta_{25-35}$ generated ROS whereas $\mathrm{A} \beta_{35-25}$ is not cytotoxic. Furthermore, $\mathrm{A} \beta_{25-35}$ was able to initiate synaptosomal lipoperoxidation, whereas $\mathrm{A} \beta_{35-25}$ had no effect (Butterfield et al., 1994).

In Fig. 5, we observed the accumulation-release-recuperation behavior of brain mitochondria probably due to the heterogeneity of brain mitochondria population. A more susceptible mitochondrial sub-population to toxic agents undergoes PTP and releases $\mathrm{Ca}^{2+}$ which can be reuptaken by other mitochondria. The $\Delta \Psi \mathrm{m}$ data (Fig. 1) also confirmed this heterogeneity: after the first $\mathrm{Ca}^{2+}$ challenge, a small drop on $\Delta \Psi \mathrm{m}$ occurred, this drop being probably due to the injury of the mitochondrial sub-population more susceptible to insults. This heterogeneity of brain mitochondria population was previously reported (Berman et al., 2000; Kristián et al., 2000).

After $\mathrm{A} \beta_{25-35}$ and/or $\mathrm{Ca}^{2+}$ induced depolarization, EGTA (a $\mathrm{Ca}^{2+}$-chelating agent) and ADP (an inhibitor of PTP) plus oligomycin (prevents ADP phosphorylation) completely repolarized mitochondria (Fig. 1), an effect that has also been 
demonstrated by others (Hunter and Haworth, 1979; Zoratti and Szabo, 1995; Brustovetsky and Dubinsky, 2000).

Another proof that $\mathrm{A} \beta_{25-35}$ promotes PTP induction is given by the protection exerted by the immunosuppressant peptide and specific inhibitor of PTP, CsA. The effect of CsA on the ability of brain mitochondria to accumulate $\mathrm{Ca}^{2+}$ was only moderate when compared with the effects described for CsA on liver or muscle mitochondria (Fontaine et al., 1998; Kristián et al., 2000). Similar effects of CsA were also reported on cell lines (Murphy et al., 1996) and neuronal primary cultures (Dubinsky and Levi, 1998). Although CsA does not give a total protection against PTP induction, it increases the capacity of brain mitochondria to accumulate $\mathrm{Ca}^{2+}$ (Figs. 3, 5). However, when ADP plus oligomycin were present initially, the $\mathrm{A} \beta_{25-}$ 35 and/or $\mathrm{Ca}^{2+}$-induced depolarization was prevented. Brustovetsky and Dubinsky (2000) also reported the protection exert by ADP plus oligomycin on brain mitochondria before calcium challenge.

Our data clearly shows that the specific amino acid sequence $\mathrm{A} \beta_{25-35}$, affects directly mitochondria leading to the uncoupling of respiration and, consequently, to promotion of PTP, thus contributing to neuronal death. The understanding of the mechanisms underlying the neurogenerative process induced by $\mathrm{A} \beta$ peptide is a fundamental step for the finding of new therapeutical strategies in Alzheimer's disease.

\section{ACKNOWLEDGMENT}

This work is supported by FCT (Portuguese Research Council). Paula Moreira is the recipient of grant PRAXIS XXI/BM/20952/99.

\section{REFERENCES}

Andreyev, A. and Fiskum, G. (1999) Cell Death Different. 6:825-832.

Beal, M. F. (1996) Curr. Opin. Neurobiol. 6:661-666.

Behl, C. (1999) Prog. Neurobiol. 57:301-323.

Berman, S. B., Watkins, S. C., and Hastings, T. G. (2000) Exp. Neurol. 164:415-425.

Bernardi, P. (1992) J. Biol. Chem. 267:8834-8839.

Bernardi, P., Broekemeier, K. M., and Pfeiffer, D. R. (1994) J. Bioenerg. Biomembr. 26:509-517.

Bernardi, P. and Petronilli, V. (1996) J. Bioenerg. Biomembr. 28:131-138.

Bindoli, A. (1988) Free Radic. Biol. Med. 5:247-261.

Boveris, A., Oshino, N., and Chance, B. (1972) Biochem. J. 128:617-630.

Broekemeier, K. M., Dempsey, M. E., and Pfeiffer, D. R. (1989) J. Biol. Chem. 264:7826-7830.

Brustovetsky, N. and Dubinsky, J. (2000) J. Neurosc. 20(1):103-113.

Butterfield, D. A., Hensley, K., Harris, M., Mattson, M. P., and Carney, J. (1994) Biochem. Biophys. Res. Commun. 200:710-715.

Chernyak, B. V. and Bernardi, P. (1996) Eur. J. Biochem. 238:623-630.

Dubinsky, J. M. and Levi, Y. (1998) J. Neurosci. Res. 53:728-741.

Estabrook, R. E. (1967) Methods Enzymol. 10:41-47.

Fontaine, E., Eriksson, O., Ichas, F., and Bernardi, P. (1998) J. Biol.Chem. 273:12662-12668.

Glenner, G. G. (1988) Cell 52:307-307.

Gornall, A. G., Bardawill, C. J., and David, M. M. (1949) J. Biol. Chem. 177:751-766.

Hensley, K. et al. (1994) Proc. Natl. Acad. Sci. USA 91:3270-3274.

Hunter, D. R. and Haworth, R. A. (1979) Arch. Biochem. Biophys. 195:453-459. 
Kamo, N., Muratsugu, M., Hongoh, R., and Kobatake, V. (1979) J. Membr. Biol. 49:105-121.

Kim, K. J., Jang, Y. Y., Han, E. S., and Lee, C. S. (1999) Mol. Cel. Biochem. 201:89-98.

Kish, S. J., Bergeron, C., Rajput, A., Dozic, S., Mastrogiacomo, F., and Chang, L. J. (1992) J. Neurochem. 59:776-779.

Kristal, B. S. and Dubinsky, J. M. (1997) J. Neurochem. 69:524-538.

Kristián, T., Gertsch, J., Bates, T. E., and Siesjö, B. K. (2000) J. Neurochem. 74:1999-2009.

Loschen, G., Azzi, A., Richter, C., and Flohe, O. (1974) FEBS Lett. 42(1):68-72.

Marchetti, P. et al. (1996) J. Exp. Med. 184:1155-1160.

Mattson, M. P. (1997) Alzheimer's Disease Rev. 2:1-14.

Mattson, M. P., Cheng, B., Davis, D., Bryant, K., Lieberburg, I., and Rydel, R. E. (1992) J. Neurosci. 12:376-389.

Mattson, M. P., Tomaselli, K. J., and Rydel, R. E. (1993) Brain Res. 553:315-349.

Moreno, A. J. M. and Madeira, V. M. C. (1991) Biochem. Biophys. Acta 1060:166-174.

Murphy, A. N., Bredesen, D. E., Cortopassi, G., Wang, E., and Fiskum, G. (1996) Proc. Natl. Acad. Sci. USA 93:9893-9898.

Parks, J. K., Smith, T. S., Trimmer, P. A., Bennett, Jr., J. P., and Parker, Jr, W. D. (2001). J. Neurochem. 76:1051-1056.

Pereira, C., Santos, M. S., and Oliveira, C. (1998) Neuroreport 9:1749-1755.

Pereira, C., Santos, M. S., and Oliveira, C. (1999) Neurobiol. Disease 6:209-219.

Petronilli, V., Costantini, P., Scorrano, R., Passamonti, S., and Bernardi, P. (1994) J. Biol. Chem. 269:16638-16642.

Pike, C. J. and Cotman, C. W. (1993) Neuroscience 56:269-274.

Rosenthal, R. E., Hamud, F., Fiskum, G., Varghese, P. J., and Sharpe, S. (1987) J. Cereb. Blood Flow Metab. 7:752-758.

Selkoe, D. J. et al. (1995) Ann. NY Acad. Sci. 777:57-64.

Smith, C. D., Carney, J. M., Starke-Reed, P. E., Oliver, C. N., Stadtman, E. R., and Floyd, R. A. (1991) Proc. Natl. Acad. Sci. USA 88:10540-10543.

Zoratti, M. and Szabo, I. (1995) Biochem. Biophys. Acta 1241:139-176. 